\title{
The Development of Educational Videos to Deliver Topics in Japanese Sociolinguistics Course
}

\author{
Kadek Eva Krishna Adnyani ${ }^{1 *}$, I Wayan Sadyana ${ }^{1}$, Gede Satya Hermawan ${ }^{1}$ \\ ${ }^{1}$ The Department of Education of Japanese Language Department, Universitas Pendidikan Ganesha, Indonesia \\ *Corresponding author.Email: krishna.adnyani@undiksha.ac.id
}

\begin{abstract}
The aim of this study was to develop appropriate educational videos for the Japanese Sociolinguistics Course and to analyze the feasibility level of educational videos for the Japanese Sociolinguistics Course in the Department of Education of Japanese Language Department, Universitas Pendidikan Ganesha. The method used was MDLC with six stages; Concept, Design, Material Collecting, Assembly, Testing, and Distribution. Data collection was carried out by semi-structured interviews and mixed questionnaires (closed-ended followed by open-ended questions). The subjects involved in this study were one content expert, one media expert, and 9 learners of Japanese Sociolinguistics Course. The objects developed in this study were four educational videos on various sociolinguistics topics. Based on the assessment results of experts of material and media, the educational videos were determined as very good and could be used with revision. Based on the small group formative evaluation, the student response were also determined as very good.
\end{abstract}

Keywords: Educational videos, Japanese linguistics, Sociolinguistics, MDLC

\section{INTRODUCTION}

Learning media is important in learning. Mentioned that using media is the key to make students have higherlevel thinking [1]. Today, students have been part of the multimedia world since they were born. Therefore, it is not surprising that today's students have difficulty sitting still in class for a long time.

For the majority of students whose learning style is visual, listening to information is not enough because they want to see it. Thus, it would be better if teachers use technology in the teaching and learning process. The reason is that technology is not limited to classrooms, creating fair opportunities for everyone to learn, and more in line with the way students learn today.

For the creation of good learning, a learning media is needed in accordance with good quality. However, in reality in the field, not all lecturers or teachers provide it optimally. One example of this phenomenon occurs in shakai gengogaku (sociolinguistics) course in the Department of Education of Japanese Language Universitas Pendidikan Ganesha (UNDIKSHA).

Japanese Sociolinguistics course is a compulsory course that must be taken by Japanese language education students with 2 credits. This course discusses language as a means of interaction and communication in the community. The thing that distinguishes this course from other sociolinguistics courses in general is that in the learning process, case studies, discussion materials, or examples used discuss more Japanese sociolinguistics in order to increase learners' insights on Japanese and Japanese linguistics. The main books used are the Routledge Handbook of Japanese Sociolinguistics edited by Patrick Heinrich and Yumiko Ohara (2019) and An Introduction to Sociolinguistics by Janet Holmes (2013).

To identify problems that may be found in the field, preliminary studies in the form of observations in the classroom as well as semi-structured interviews on three students and a lecturer who lecturing the courses have been conducted. Based on observation, lecturers conducted teaching and learning process using PowerPoint media. In addition, students were also divided into 5 groups per class (1 group consisting of 3 students) to present various topics related to the material of Japanese Sociolinguistics Course.

Based on the interview, students argued that broadly speaking, the motivation of students to study is still lacking. Presentations made by lecturers and other students (in groups) had not been able to make students 
interested and motivated to learn because of the lack of attractive appearance. In addition, students found it difficult and got bored to study outside the classroom (outside of study hours) because they considered the reference books used by the material to be quite hard and difficult to understand because they were in English.

Students need an introduction to guide them in getting an initial overview of the material (so that it can be easier to understand the contents of the reference book), which is presented interestingly, and can help their learning process outside the classroom. If technology is used, such as learning video media, it will be better. The reason is that students can study anytime and anywhere by simply accessing from their smart phones.

Based on interviews with lecturers who are lecturing shakai gengogaku courses, it was known that the lecturer had observed the situation in the classroom and seen that the students were less motivated and got bored. The lecturer then had the initiative to find a learning video suitable to be used both in the classroom and outside the classroom. Learning videos were considered necessary to stimulate students' learning interests and could also make it easier for students to study at home. But it turned out that no suitable video were found.

Generally, available learning videos are more about sociolinguistic material in general, not yet associated with Japanese sociolinguistics. Based on the identification of the problems that have been presented, it is necessary to develop a learning video that is suitable for the course of shakai gengogaku. The development method to be used is MDLC (Multimedia Development Life Cycle).

States that the effectiveness of video as an educational tool will increase if the instructor considers the following three elements: 1 ) how to set the cognitive load of the video 2) how to maximize student engagement with the video and 3) how to promote active learning using video. Therefore, the development of the video will consider the three elements [2].

Research on multimedia development has been done before to develop diverse science and technology products.

Developed Japanese language learning media based on Adobe Flash Professional CS6 in improving the ability to memorize vocabulary in accordance with the Japanese language Syllabus XI grade students of SMKN 4 Negara. The results showed that based on the assessment results of experts of material and media and small group formative evaluation, the learning media were suitable with the Japanese language syllabus of SMKN 4 Negara [3].

Developed interactive learning media in project management courses using MDLC method. The media contains an explanation of the stages of initialization, planning, implementation, supervision, and closure of projects as well as the necessary documents in the construction of IT projects. The application has been tested using black box testing, with all indicators declared good [4]

Designed the educational game "Petualangan Dino dan Dina" using MDLC method. This game was developed to help elementary school students in understanding five main values, namely religious, nationalist, independent, helpful, and integrity. Based on the results of the black box test, this game works well and as being expected [5].

Designed a multimedia-based interactive learning application that will be useful to increase students' learning motivation about the introduction of alphabets and numbers. The research method using MDLC. Sugiarto concluded that multimedia-based interactive learning that is attractively designed will generate motivation and stimulation of learners' learning activities, help learners improve understanding of learning materials and foster learning creativity so that it will have an impact on improving the quality of learning [6].

Finally, developed learning media that can introduce practicum tools to students of X Chemistry Analyst. The research used MDLC method. The result of the research is an application for the introduction of basic chemical practicum tools equipped with games and quiz to improve students' ability to recognize practicum tools [7].

In line with the background described, the problem can be formulated as follows:

1. What is the appropriate form of learning video for Japanese Sociolinguistics courses in the Department of Education of Japanese Language UNDIKSHA?

2. What is the feasibility level of learning videos for Japanese Sociolinguistics courses in the Department of Education of Japanese Language UNDIKSHA?

\section{METHOD}

The method used in the development of video learning courses of shakai gengogaku is MDLC method. Modified Luther-Sutopo's multimedia software development method by adding one more stage that connects the last stage (distribution) to the initial stage (concept) so that if there is a new problem, it can be resolved immediately [8]. 


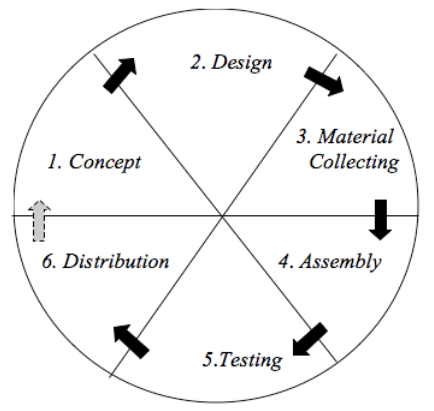

Figure 1 Multimedia Development Methodology of Luther-Sutopo (revised by Binanto)

The subjects involved in this study were one content expert, one media expert, and 9 students of The Department of Japanese Language Education of UNDIKSHA semester 7 for small group test. While the object involved in this study is a learning video for the material of shakai gengogaku.

Data collection was conducted with non-participatory observations, questionnaires, and semi-structured interviews. Instruments used in the form of observation guidelines, mixed questionnaires (open and closed), and interview guidelines.

Questionnaires used at the testing stage were a combination of [9] which evaluated the video by paying attention to 4 aspects including Content, Instructional Plan, Technical considerations, as well as Supplemental materials (complementary materials, information accompanying the video and [10] which evaluated videos by dividing expert questionnaires into 2 aspects; (material quality and material usefulness) and media expert questionnaires into 3 aspects (media quality, language usage, media layout).

In small group trial instruments, in addition to being adapted from [9] and [10] it was also combined with [11] which mentioned that the focus of questions for small group evaluation in general includes several aspects such as 1) effectiveness and efficiency, 2) implementation, 3) material, and 4) learning design.

\section{RESULTS AND DISCUSSION}

\subsection{Results}

\subsubsection{Concept}

Concept is the initial stage of the multimedia development method. In the current research, the purpose of the research is to develop learning videos on the subjects of Japanese Sociolinguistics Course which is interesting and easy to understand. The purpose of the product is to provide information. The audience were the students of The Department of Education of Japanese Language UNDIKSHA. The four learning videos developed have different topics with major themes taken from the reference book used (Routledge Handbook of Japanese Sociolinguistics).

\subsubsection{Design}

At this stage the author made detailed specifications about the architecture of the project. In the research, the design stage was done by using storyboard as a tool at the stage of multimedia design. Storyboard is a graphic organizer, for example a series of illustrations or images displayed for visualization purposes. To develop four learning videos, four storyboards have been designed which concepts have been adapted to the function of learning videos according to [12] namely to increase efficiency, generate motivation, facilitate active learning, and as an alternative in the teaching and learning process.

\subsubsection{Material Collecting}

At this stage, the author conducted the collection of materials in accordance with the needs of the work.. In this study, the material collection stage was done by shooting in the form of video. The shooting took place in the Photography and Video Lab Room, Education Technology study program of FIP Undiksha.

\subsubsection{Assembly}

At this stage, the creation of all objects or multimedia materials was conducted. In this research, the creation stage was done by video editing process.

\subsubsection{Testing}

Testing was conducted after completing the assembly stage by running the application and noticing if there is an error or not. When the learning media product is completed, a testing stage consisting of alpha trial stage and beta trial stage are carried out. Alpha trial stage is carried out by media experts and material experts. When the results of the media trial meets the criteria of feasibility, then beta trials will conducted by application users, in this study small group trials were conducted.

The assessment by the content and media experts was performed once the video were finished.

1) Based on the validation by the expert of content, it is obtained the following results. 


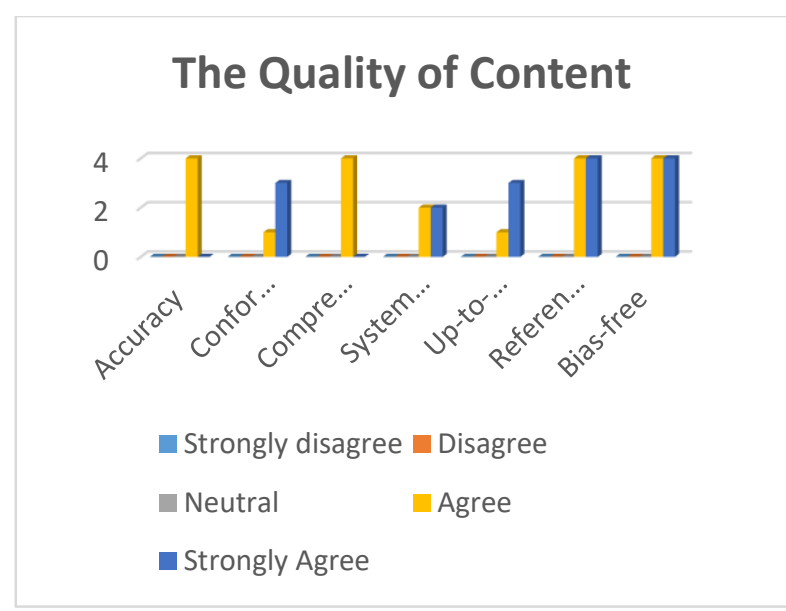

Figure 2 The Material Expert Judgement (Aspect: Quality of Content)

\section{The Benefit of Content}

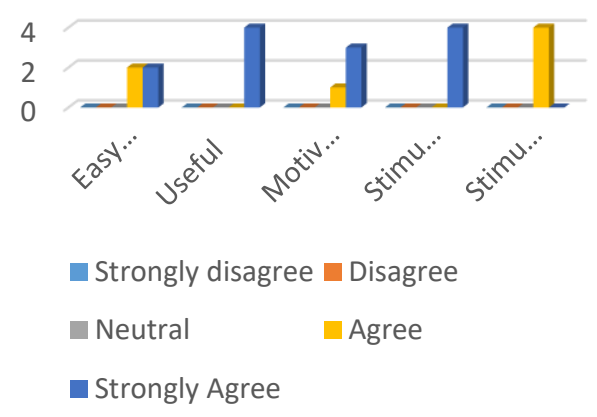

Figure 3 The Material Expert Judgement (Aspect: The Benefit of Content).

Based on the Validation of the expert in media, it is obtain the following results:

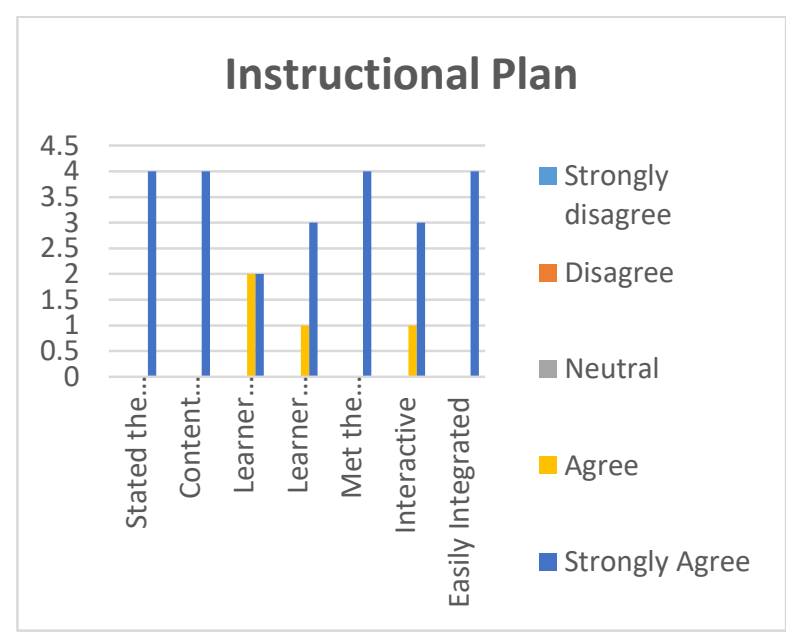

Figure 4 The Media Expert Judgment (Aspect: Instructional Plan)

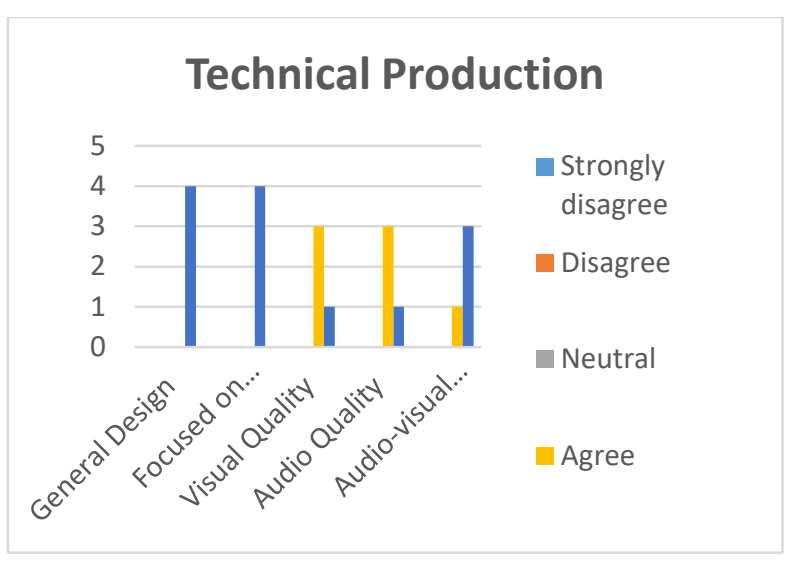

Figure 5 The Media Expert Judgment (Aspect: Technical Production)

The results of the assessment of experts are later calculated and converted using the following formula from [13].

Table 1. Conversion Formulas

\begin{tabular}{|c|c|}
\hline Score & Criteria \\
\hline $\mathrm{X} \geq \mathrm{Mi}+1.5 \mathrm{Sdi}$ & Very Good \\
\hline $\mathrm{Mi}+0.5 \mathrm{Sdi} \leq \mathrm{X} \leq \mathrm{Mi}+1.5 \mathrm{Sdi}$ & Good \\
\hline $\mathrm{Mi}-0.5 \mathrm{Sdi} \leq \mathrm{X} \leq \mathrm{Mi}+0.5 \mathrm{Sdi}$ & Fair \\
\hline $\mathrm{Mi}-1.5 \mathrm{Sdi} \leq \mathrm{X} \leq \mathrm{Mi}+0.5 \mathrm{Sdi}$ & Less Good \\
\hline $\mathrm{X}<\mathrm{Mi}-1.5 \mathrm{Sdi}$ & Bad \\
\hline
\end{tabular}

$\mathrm{Mi}=1 / 2($ Score Max + Score Min $) \mathrm{Sdi}=1 / 3(\mathrm{Mi})$

$\mathrm{Mi}=$ the Ideal Mean

Sdi $=$ the Standard of Deviation

$\mathrm{X}=$ The Score of the teacher.

The data analysis is explained as follow.

Table 2. Determining X, Mi, and Sdi (Expert Judgment)

\begin{tabular}{|c|c|c|c|}
\hline No. & Note. & $\begin{array}{c}\text { Material } \\
\text { Expert }\end{array}$ & $\begin{array}{c}\text { Media } \\
\text { Expert }\end{array}$ \\
\hline 1 & $\mathrm{X}$ & \multicolumn{1}{|c|}{55,25} & 52,75 \\
\hline 2 & $\mathrm{Mi}$ & $\begin{array}{l}\mathrm{Mi}=1 / 2(\text { Score Max } \\
+ \text { Score Min) } \\
=1 / 2(60+12) \\
=1 / 2(72)=36\end{array}$ & $\begin{array}{r}\text { Score Max } \\
=1 / 2(60+12) \\
=1 / 2(72)=36\end{array}$ \\
\hline 3 & Sdi & $\begin{array}{l}1 / 3(\mathrm{Mi}) \\
1 / 3(36)=12\end{array}$ & $\begin{array}{l}1 / 3(\mathrm{Mi}) \\
1 / 3(36)=12\end{array}$ \\
\hline
\end{tabular}

After finding $\mathrm{X}, \mathrm{Mi}$, and Sdi, $\mathrm{X}$ is then converted in accordance with Table 1 . and the results are as follow:

$$
\begin{aligned}
\text { Content Expert: } & \mathrm{X} \geq \mathrm{Mi}+1 / 2 \mathrm{Sdi} \\
& : 55.25 \geq 36+6 \\
& : 55.25 \geq 42(\text { Very Good) }
\end{aligned}
$$


Media Expert: $\mathrm{X} \geq \mathrm{Mi}+1 / 2 \mathrm{Sdi}$

$$
: 52.75 \geq 36+6
$$$$
52.75 \geq 42 \text { (Very Good) }
$$

After revision, small groups formative evaluation was carried out using questionnaires. The results of the students' responses are outlined in Table $4-6$.

Table 3. Small Group Formative Evaluation (Learning Design)

\begin{tabular}{|c|l|c|}
\hline No. & \multicolumn{1}{|c|}{ Aspect } & Average Score \\
\hline 1 & Delivering Strategy & 4.11 \\
\hline 2 & Language & 4.33 \\
\hline 3 & Picture & 4.66 \\
\hline 4 & Sound & 4.11 \\
\hline \multicolumn{2}{|c|}{ TOTAL } & 17.21 \\
\hline
\end{tabular}

Table 4. Small Group Formative Evaluation (Implementation)

\begin{tabular}{|c|l|c|}
\hline No. & \multicolumn{1}{|c|}{ Aspect } & Average Score \\
\hline 1 & Easy to Use & 4.33 \\
\hline 2 & Usefulness & 4.44 \\
\hline 3 & Motivating & 4.11 \\
\hline 4 & Increase Curiousity & 4.44 \\
\hline 5 & Stimulating Activity & 3,77 \\
\hline 6 & Interactive & 4 \\
\hline \multicolumn{2}{|r|}{ TOTAL } & 25.09 \\
\hline
\end{tabular}

Table 5. Small Group Formative Evaluation (Material)

\begin{tabular}{|c|l|c|}
\hline No. & \multicolumn{1}{|c|}{ Aspect } & Average Score \\
\hline 1 & Interesting & 4.33 \\
\hline 2 & Appropriate & 4.44 \\
\hline 3 & Complete & 4.11 \\
\hline 4 & Systematic & 4.44 \\
\hline \multicolumn{2}{|c|}{ TOTAL } & 16.66 \\
\hline
\end{tabular}

$$
X=17.21+25.09+16.66=\mathbf{5 8 . 9 6}
$$

Table 6. Determining X, Mi, and Sdi (Small Group Formative Evaluation)

\begin{tabular}{|c|l|l|}
\hline No. & \multicolumn{1}{|c|}{ Note. } & \multicolumn{1}{c|}{$\begin{array}{c}\text { Material } \\
\text { Expert }\end{array}$} \\
\hline 1 & $\mathrm{X}$ & 58.96 \\
\hline 2 & $\mathrm{Mi}$ & $\begin{array}{r}\mathrm{Mi}=1 / 2(\text { Score Max + Score Min }) \\
=1 / 2(70+14) \\
=1 / 2(84)=42\end{array}$ \\
\hline 3 & Sdi & $1 / 3(\mathrm{Mi})$ \\
\hline
\end{tabular}

\begin{tabular}{|l|l|l|}
\hline & $1 / 3(42)=14$ \\
\hline
\end{tabular}

After finding $\mathrm{X}, \mathrm{Mi}$, and $\mathrm{Sdi}, \mathrm{X}$ is then converted in accordance with Table 1. and the results are as follow:

Small Group Formative Evaluation:

$$
\begin{aligned}
& \mathrm{X} \geq \mathrm{Mi}+1 / 2 \text { Sdi }: \\
& 58.96 \geq 42+7: \\
& 58.96 \geq 49 \text { (Very Good) }
\end{aligned}
$$

\subsubsection{Distribution}

The distribution stage is the last stage in the MDLC method. Distribution is done after the application is declared feasible. In this research, the distribution stage was done by uploading learning videos to Youtube and the link was uploaded in the Learning Management System used by Schoology.

\subsection{Discussion}

Based on the assessment results of experts of material and media, the educational videos were determined as very good and could be used with revision. Based on the small group formative evaluation, the student response were also determined as very good. Both positive and negative comments were used to revise the product.

The responses are dominated with positive ones, i.e. agree and strongly agree. However, there are statements with the responses of neutral. Nevertheless, the particular responses are very rare. In addition, the response of "disagree" and "very disagree" does not appear on all of the statements. On the questions "do you want to use it in learning the course of Japanese Sociolinguistics when the learning video has been developed?", 100\% students answered "yes".

The results showed that the educational videos has been made in accordance with the theory of [12] which mentioned the function of learning videos namely to increase efficiency, generate motivation, facilitate active learning, and as an alternative in the teaching and learning process.

\section{CONCLUSION}

I argued at the beginning of this article that it is important to do research on the development of educational videos to deliver topics in Japanese Sociolinguistics Course. It is expected that with the use of technology in the learning process, students will be more interested in learning and it is easier to learn anywhere and anytime. 
The findings that have been presented suggest that based on the assessment results of experts of content and media and small group, the educational videos were determined as very good and could be used with revision. The student response on Schoology was predominately positive, i.e. agree and strongly agree. The research is important for Japanese language education students and lecturers because it helps to meet the need of "anywhere any device" aspect of flexible learning.

As a result of conducting this research, I propose that there are several benefits of using educational videos in the learning process, such as: 1) it provides unlimited access to learning material, 2) it increases curiousity, and 3 ) it is easy to use.

It would be fruitful to pursue further research about the impact of blended learning by using educational videos in the Japanese Sociolinguistics course in order to investigate whether or not there is a significant difference in competency between students who learn in blended learning environment by using educational videos and those who learn in conventional environment.

\section{AUTHORS' CONTRIBUTIONS}

Adnyani and Hermawan conceived of the presented idea. Sadyana and Hermawan developed the theory and performed the calculation. Adnyani verified the analytical methods. Sadyana supervised the findings of this work. All authors discussed the results and contributed to the final manuscript.

\section{ACKNOWLEDGMENTS}

This work was funded by DIPA BLU Universitas Pendidikan Ganesha (March, 2020).

\section{REFERENCES}

[1] D.W. Tileston, What Every Teacher Should Know About Using Media and Technology, Corwin Press, 2004.

[2] C.J. Brame,Effective Educational Videos: Principles and Guidelines for Maximizing Student Learning from Video Content, CBE - Life Sciences Education, 15 (4) (2017).1-6 DOI: https://doi.org/10.1187/cbe.16-03-0125

[3] I.G.N.A. Keniten, K.E.K.Adnyani, G.S. Hermawan., Pengembangan Media Pembelajaran Bahasa Jepang Berbasis Adobe Flash Professional CS6 Untuk Meningkatkan Kemampuan Mengingat Kosakata Siswa Kelas XI di SMKN 4 Negara, Jurnal Pendidikan Bahasa Jepang, 3(1) (2017) 33-43. DOI : http://dx.doi.org/10.23887/jpbj.v3i2.11193

[4] M. Mustika, E.P.A, Sugara, M. Pratiwi, Pengembangan Media Pembelajaran Interaktif dengan Menggunakan Metode Multimedia Development Life Cycle, Jurnal Online Informatika 2(2) (2017) 121-126. DOI : https://doi.org/10.15575/join.v2i2.139

[5] S.L.Rahayu, Educational Games as A learning media of Character Education by Using Multimedia Development Life Cycle (MDLC), in: Proceedings of the 6th International Conference on Cyber and IT Service Management (CITSM), Medan, 2018, pp. 240-243.

[6] H. Sugiarto, Penerapan Multimedia Development Life Cycle Pada Aplikasi Pengenalan Abjad Dan Angka, IJCIT (Indonesian Journal on Computer and Information Technology) 3(1) (2018) 26-31. DOI : https://doi.org/10.31294/ijcit.v3i1.3753

[7] M. Lathifah, R.W.Arifin, Animasi Interaktif Pengenalan Alat - Alat Praktikum Untuk Siswa Kelas X Kimia Analis Pada SMKN 5 Kota Bekasi, Information System For Educators and Professionals 3(2) (2019) $189-200$.

[8] I. Binanto, Multimedia Digital-Dasar Teori dan Pengembangannya, Andi, 2010.

[9] B. P. Beaudin, D. Quick, Instructional Video Evaluation Instrument, Journal of Extension 34 (3) (1996) Available at: https://www.joe.org/joe/1996june/a1.php (Accessed: 15 July 2020).

[10] P. Aria, Pengembangan Media Pembelajaran Video Tutorial pada Mata Pelajaran Kompetensi Kejuruan Standar Kompetensi Melakukan Pekerjaan dengan Mesin Bubut di SMK Muhammadiyah 1 Playen, B.A Thesis. Universitas Negeri Yogyakarta. Available https://core.ac.uk/download/pdf/33526888.pdf (Accessed: 18 June 2020).

[11] M. Tessmer, Planning and Conducting Formative Evaluations (Teaching in Higher Educations). Routledge, 2013.

[12] T. Limbong, J. Simarmata, Media dan Multimedia Pembelajaran: Teori \& Praktik, Yayasan Kita Menulis, 2020.

[13]W. Nurkancana, Sunartana, Evaluasi Hasil Belajar, Usaha Nasional, 1992. 